\title{
Development of Teaching Material for Narrative Writing Using Graphic Organizer Type Circle Organizer in Elementary School
}

\author{
Darma Aswita, Syahrul R, Taufina Taufik \\ Universitas Negeri Padang \\ darmaaswita@gmail.com
}

\begin{abstract}
The rationale of this research was the use of teaching materials that were less attractive and appropriate with the writing process (pre-writing, during the writing, and post-writing). Hence, this study aimed at describing the process of developing teaching materials for writing narrative and producing narrative writing using Graphic Organizer especially Circle Organizer type for teachers and students of grade $V$ that is valid, practical, and effective. Moreover, this type of research was research and development which used 4-D model. This model consists of 4 stages: define, design, develop, and disseminate. Validity test data were obtained through teachers and students' response on assessment sheets. Furthermore, the effectiveness was seen from students' activity, assessment process and result of students' writing. Based on the results of validity, practicality, and effectiveness tests, teaching material which were valid, practical, and effective were able to improve students' narrative writing skill. Thus, it can be concluded that teaching material of narrative writing using Graphic Organizer especially Circle Organizer type can be used in narrative writing lesson for grade V students at Elementary School.
\end{abstract}

Keywords-Graphic Organizer; Circle Organizer; Writing narrative; teaching material

\section{INTRODUCTION}

Writing skills is one of the skills in Indonesian language that teachers must teach to students (Koura \& Zahran, 2017). Much of the research on writing skills that has been done by various researchers in many countries such as Malaysia (Jalaluddin, Yunus, and Yamat, 2011), Iraq (Muslim, 2014), Pakistan (Fareed, Ashraf, Muhammad, 2016), Turkey (Ozturk, 2014), Mumbay (Deshpande, 2014) came up with the same conclusion. They state that writing skill is important to be taught and it tests the students' ability to be able to issue their ideas through written language, as well as overcome student difficulties in writing, such as vocabulary, language, spelling, and punctuation. However, there are several factors that affect learning how to write in Indonesian, especially in writing narrative text (Koura \& Zahran, 2017). Such factors can be internal factors derived from within the students themselves (Muslims, 2014), and external factors, such as teachers, methods, teaching materials, and the environment (Wahyuningtyas, Maryaeni, Roekhan, 2016).

The internal factors derived from the students themselves are shown in the research that has been carried out by Rahim (2017), Herlina (2015) Hamidun, Hashim, and Othman, (2012), Bulut (2017). The results revealed that the motivation and self-confidence that they have within themselves affect the writing skill. Writing skill is not only influenced by internal factors but also external factors, i.e. teachers, methods used by teachers, the environment, and teaching materials (Herlina, 2015). In learning writing skill, teaching materials are also influential and supportive in the process of writing skills. Slamet, Winarni, Ismail, (2015) state that if the teaching materials are used effectively, it will improve students' writing skill.

Related to narrative writing skill, the results of some research in several countries, such as in Indonesia (Kumara, 2016), Netherlands (Torkildsen, 2015), Nepal (Sapkota, 2012), China (Mo Haiwen, 2012), UK (Keen, 2017), Pakistan (Dastgeer and Afzal, 2015), Russia (Terenin, 2013) show various problems in learning narrative writing skill, namely (1) paying less attention to format, distance, spelling, grammar and punctuation while writing the essay, (2) inappropriate assessment on students' writing, and (3) inappropriate teaching approach used by the teacher while teaching writing.

Based on the result of preliminary study in grade V SD Negeri 62 Batu Hampar Lubuk Basung regency, there were some problems found in learning writing narrative text. The problems were (1) the students felt confused how to start writing narrative story, (2) students got less guidance from teachers (4) the students had difficulty in choosing the right vocabulary in pouring their ideas, and (5) the approach and strategy used by the teacher was less interesting so that it affected the student's interest in writing. Besides, similar issues are also found by Mustava, Devy, Anggraini, Ina (2016), Quastantia, Lia, Noviana (2017), and Masood (2013).

There were several other problems found. Firstly, teaching materials were less attractive that make it difficult for teachers to develop diverse learning materials. Secondly, writing processes namely pre-writing, writing, and postwriting in the teaching materials used were incomplete. As a result, students only focused on the content of the writing without paying attention to what must be prepared before writing and after writing which are format, space, spelling, 
and punctuation. Next, teaching materials did not contain varied themes and story topics, thus it affected students' reading interest. As it is found by Masood (2013) in his study, students experience three problems which are lacking of available materials and having difficulties in determining the topic, and getting confused in beginning and ending of writing process. Lastly, the teaching material used has not included a writing strategy that describes a regular flow so that the teacher has difficulty in developing a suitable strategy in teaching writing. As a result, students' essays tend to be less sequential and do not have a systematic flow.

Learning writing will be interesting and fun if the teaching materials used by teachers are interesting as well, it is in accordance with the needs and characteristics of students (Wahyuni, 2017), and it is not apart from the basic competencies that exist in the curriculum and indicators that have been compiled by teachers.

Based on the above explanation, it is deemed necessary to have teaching materials that are easily understood by the students and provide information related to writing skill (Tomlison, 2012). One of the strategies that can be used in developing materials for teaching writing is using Graphic Organizer. Faull (2007) in his research revealed that using Graphic Organizer could add variation in the process of learning to write. Furthemore, this model can help students organize information into a structured concept and it connects it with another concept (Zaini, Mokhtar, \& Nawawi, 2010).

Graphic organizer is used by teachers to support learning. One of the suitable types of Graphic Organizer used to develop writing narrative teaching materials is circle organizer. This graph can be used to help students to understand the sequence of events experienced in a coherent and orderly manner. Each circle represents the sequence of events experienced by students (Education Dept Hong Kong, 2001). This is proven in the research conducted by Tayib AbdulMajeed Tayib (2015), Lancaster, K (2013), Chien, C, W. (2012), Pratama Suhaidi, Rahmawati, and Irfani (2017), Ibnian (2010) Mercuri (2010), Liou Hsien Chin (2014) who stated that the use of graphic organizers is influential in improving and developing writing skill for students.

\section{METHODS}

The type of the research was a research and development. Sukmadinata (2010) mentions that research and development is a type of research which involves some processes or steps to develop a new product or refine existing products and can be accounted for. The development model in this research used 4-D development model. According to Thiagarajan (in Sugiyono, 2015:37), the stages in the 4-D model stages are: "define, design, development, and disseminate)." In the define stage, curriculum analysis, needs analysis, and student analysis were performed. The results of this analysis were used as a reference in designing teaching materials (design). Furthermore, the design stage was done by designing teaching materials using Graphic Organizer especially Circle Organizer type in grade V. Then, teaching materials were designed. Furthermore, the development of the teaching materials in elementary school no 62 Batu Hampar, Lubuk Basung regency with the number of students 17 was done. The development stage included the test of validity, practicality, and effectiveness. Validity test was done to the aspect of content, language, and graphic of teaching materials. Instrument used was validation sheet of content material, language and instructional material grant. The next stage was practicality test which aimed to see the level of convenience and practicality of the developed teaching materials. The instruments used were observation sheets for lesson plan, teachers' response questionnaire, and students' response questionnaire. Then, effectiveness test was done to determine the maximum expected objectives through the developed teaching materials. The instruments used were observation sheets of student activity on effectiveness, assessment sheet of narrative writing process, and scoring sheet of narrative text produced by the students. Lastly, dissemination stage was carried out to see the effectiveness of the developed teaching materials. The distribution was done in Elementary School no 35 Pasar Durian, Lubuk Basung, with the number of students 20. This was done to see the effectiveness of teaching materials in other schools, with different environmental conditions and students.

\section{FINDING AND DISCUSSION}

The results of research on the development of teaching materials for teaching writing narrative text using Graphic Organizer type Circle Organizer in grade V SD were seen from the level of validity, practicality, and effectiveness.

\section{Validity}

Validation that was done on this teaching material was emphasized on the content and constructs and it was seen from several aspects, content, language, and graffiti aspects. Validation in this research was done by 6 expert validators who are expert on certain field of study. 3 validators focused on content and linguistic, and the others focused on the graphic aspect. Additionally, 3 practitioners who are elementary school teacher also acted as the validator. Validation is completed, if the validator declare valid to the teaching materials. Thus, it is ready for trial. Validation results from expert validators indicated that the teaching material of narrative writing using Graphic Organizer Circle Organizer type was $91.8 \%$ valid with very valid criterion. Meanwhile, from validator's practitioners, the results showed $93.3 \%$ valid with very valid criteria. Therefore, this teaching material was valid in terms of content and constructs. This was in 
accordance with validation results from expert validators and validator of education practitioner. These results illustrated that the developed teaching material has been valid and can be used in the learning process.

\section{Practicality}

After the validation process with the experts and practitioners of education was completed, a trial to see the practicality of teaching materials was done. Trial was conducted in 3 meetings, and it was observed by 2 observers. Practices that were observed were the level of implementation of lesson plan, teachers' response questionnaire, and students' response questionnaires to the practicalities of learning tools. The results of observations during the trial showed that learning using this teaching material which was in accordance with the planning that has been made was very practical with $89.5 \%$ practicality level. Furthermore, the result of questionnaire from teacher response was $92.5 \%$ with very practical category, while the result of student response questionnaire was $90.9 \%$ with very practical category. This shows that the teaching material of narrative writing using Graphic Organizer Circle Organizer type was very practical to be used in grade $\mathrm{V}$.

\section{Effectiveness}

Teaching materials are said to be effective when it gives effect or influence both to the achievement and objectives of learning. The effectiveness of instructional material is seen from the students' activity during the learning process and the assessment of the learning process of writing narrative text and the result of the students' narrative writing. Based on the results of data analysis on student activity, the percentage of learning process was $91.4 \%$. This result indicated very good category. Similarly, the result of assessment of learning process was $84.03 \%$ and it was in very high category. Then, the result of writing skill was also in very high category which was $87.8 \%$. Therefore, the result of observation on students' activity, assessment process, and the result of students' narrative writing gave a very good description, meaning that the use of this teaching material has been effectively implemented. The results of this study can be seen in the following tables and diagrams.

\begin{tabular}{cllrl}
\hline \multirow{2}{*}{ No. } & \multicolumn{1}{c}{ Aspect } & Persentase & \multicolumn{1}{c}{ Category } \\
\hline \multirow{2}{*}{1.} & Validity & Content & $91,8 \%$ & Very Valid \\
\cline { 3 - 4 } & & Language & $93,2 \%$ & Very Valid \\
\cline { 3 - 4 } & Graphic & $92,2 \%$ & Very Valid \\
\hline \multirow{2}{*}{2.} & Practicallity & Lesson Plan Implementation & $89,5 \%$ & Very Practice \\
\cline { 3 - 4 } & & Teachers' Response & $92,5 \%$ & Very Practice \\
\cline { 3 - 5 } & Etudents' Response & $90,5 \%$ & Very Practice \\
\hline 3 & Effectiveness & Students'Activity & $91,4 \%$ & Very High \\
\cline { 3 - 5 } & & Writing Process & $84,03 \%$ & Very High \\
\cline { 3 - 4 } & & The Result of Writing & $87,8 \%$ & Very High \\
\hline
\end{tabular}

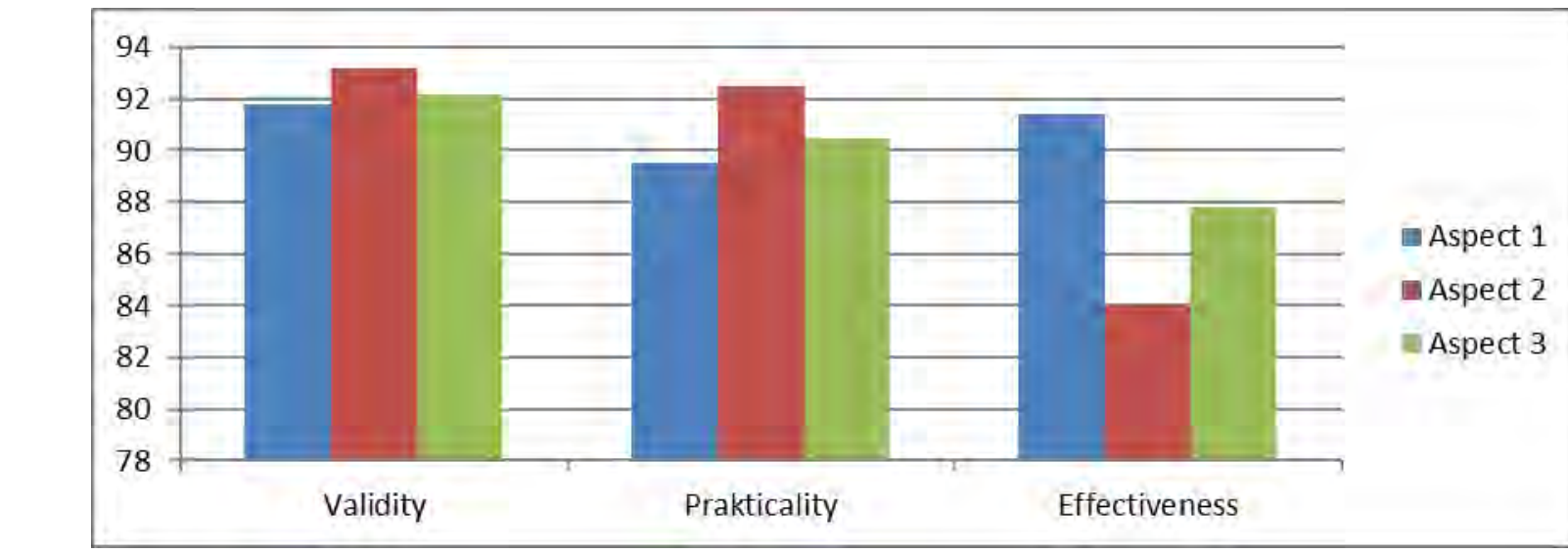

Note:

Validity

Aspect 1

Aspect 2

Aspect 3
: Content

: Language

: Graphic
Practicality

Lesson Plan Implementation

Teachers' Response

Students' Response
Effectiveness

Students'Activity

Writing Process

The Result of Writing 


\section{CONCLUSION}

Based on the development and experiments that have been conducted on this teaching materials using Graphic Organizer Circle Organizer type in Grade V Primary School, the development of this teaching materials from the validity aspect indicates that this teaching material had a very valid category level both in terms of content and constructs. This was based on the validation results from expert validators and validator of education practitioners. These results illustrate that the developed writing material has been valid and can be used in the learning process. Moreover, the result of practicality showed that the teaching material was very practical both in terms of the application and implementation. This result was seen from the implementation of lesson plan, teacher's response questionnaire, and student response questionnaire results. The results of effectiveness indicates that the development of writing materials using Graphic Organizer Circle Organizer type in grade V has been declared effective to improve the achievement of student writing skill. Therefore, this teaching material is ready to be implemented to students since it has fulfilled the criteria of validity, practicality and effectiveness.

\section{References}

Bulut, P. (2017). The effect of primary school student's writing attitudes and writing self-efficacy beliefs on their summary writing achievement, International Electronic Journal of Elementary Education, 10(2), 281-285

Chien, C, W. (2012). Use of graphic organizers in a language teachers' profesional development, Journal English Language Teaching, 5(10), 49-57

Dastgeer, G, dan Afzal, M, T. (2015). Improving english writing skill: a case of problem based learning, American Journal of Education Research, 3(10), 1315-1319

Deshpande, S. (2014). Teaching writing skills in english: involvement of students in the assessment and correction of their own errors, International Journal of English Language Teaching, 3(1) 68-73

Education, Dept Hong Kong. (2001). The Use of Graphic Organizer to Enhance Thinking Skills in the Learing of Economics. Hongkong: Cadal

Fareed, M, \& Ashraf, A, \& Muhammad. B. (2016). ESL learners' writing skills: problems, factors and suggestions, Journal of Education and Social Sciences, 4(2), 81-92

Faull, T. (2007). Writing A-Level English literature essays: Professional reflection on text organization. English Teaching Practice and Critique, 6(1), 164-174

Hamidun, H, Hashim, S, H, Md, and Othman, N,F. (2012). Enhancing student's motivation by providing feedback on writing: the case of international students from Thailand, International Journal of Social Science and Humanity, 2(6), 591-594

Herlina (2015). Improving writing skills of the 4th grade primary school students through flash cards media, Indonesian Journal of Educational Review, 2(2), 1-14

Ibnian, S, S, K. (2010) The effect of using the story-mapping technique on developing tenth grade student's short story writing skills in efl, Journal English Language Teaching, 3 (4), 181-194

Jalaluddin, I, Yunus, Md, M, \& Yamat, M. (2011). The effect of teachers' assistance on malaysia rural learner's writing self-efficacy: a case study, Journal Advances in Language and Literacy Studies, 2(1), 81-91

Keen, J. (2017). Teaching the writing process, International Journal Changing English Studies in Culture and Education, 24(4), 372-385

Koura, A, A \& Zahran, F, A. (2017). Using habits of mind to develop EFL writing skills and autonomy, Arab World English Journal, 8(4), 183-198

Kumara, A. (2016). Dampak kemampuan verbal terhadap kualitas ekspresi tulis, jurnal Psikologi, 2(1), 35-40

Lancaster, K. (2013). An Examination of Using Graphic Organizers to Teach Writing: A Case Study. Eric Doc

Liou H, C. (2014). The effects of computerized graphic organizers on students' performance in english reading and writing tasks, International Journal of Computer-Assited Language Learning and Teaching, 4(3), 1-19

Masood, A. (2013). Exploiting authentic materials for developing writing skills at secondary level, Journal of Literature, Languages and Linguistics, 1(1), 15-25

Mercuri, S, P. (2010). Using graphic organizers as a tool for the development of scientific language, Gist Education and Learning Research Journal, IV(1) 30-49

Mo, H. (2012). A study of the teaching of esl writing in colleges in China, International Journal of English Linguistict, 2(1), 118-127

Muslim, I, M. (2014). Helping EFL student improve their writing, International Journal of Humanities and Social Science, 4(2) 105-112

Mustava, D, A, I \& Anwar, E. (2016). Pengembangan bahan ajar pembelajaran menulis cerita berbasis pendekatan proses bagi siswa SMP, Journal Lingtera, 3 (1), 1-8.

Ozturk, B, K. (2014). Turkish language teachers' opinions on teaching writing and students' story writing skills, International Journal of Language Academy, 2(4), 170-194 
Pratama, S, \& Rahmawati, I, N, \& Irfani, B. (2017). Graphic organizer as one alternative technique to teach writing, Jurnal English Education:Tadris Bahasa Inggris, 10(2), 344-357

Qostantia, L, N. (2017). Bahan ajar menulis cerita fabel dengan stimulus film finding nemo. Jurnal Pendidikan, Teori Penelitian, dan Pengembangan, 2(3), 377-384

Rahim, M, A, A, Rustam, R, M,d, Primsuwan P, Amat, R, Yusof, S,M, \& Tahir, N, Md. (2017). The effectiveness of using wh-questions in improving the writing skill of upper primary school students in Malaysia, International Journal of Development Reseacrh, 7(9), 15466-15470

Sapkota, A. (2012). Developing students' writing skill through peer and teacher correction: an action research, Journal of Nepal English Language Teacher's Association, 17(1-2), 70-82

Slamet, St, Y, Winarni, R, Ismail, M. (2015). The development of text book to write story based on caracter education in contextual learning, International Journal on Studies in English Language and Literature (IJSELL), 3(7), 43-50

Sugiyono. (2015). Metode Penelitian Pengembangan Research and Development. Bandung: Alfabeta

Sukmadinata, S. (2010). Metode Penelitian Pendidikan. Bandung: Remaja Rosdakarya

Tayib, A-M. (2015). The effect of using graphic organizer on writing (a case study of preparatory college students at Umm-Al-Qura University), Internastional Journal of English Language and Linguistics Research, 3 (1), 15-36

Tomlison, B. (2012). Materials development for language learning and teaching, Cambridge Journal, 45(2), 143-179

Torkildsen, J. V. K, Morken, F, Helland W.A. \& Helland, T. (2015). The dynamics of narrative writing in primary grade children: writing process factors predict story quality, Cross Mark Journal Read Write, 3(29), 529-554

Wahyuni, S. (2017). Developing writing materials based on CTL approach for Indonesian EFL learner, Journal on English as A Foreign Language, 7(1), 97-118

Wahyuningtyas, R, N, Maryaeni, \& Roekhan, (2016). Pengembangan bahan ajar menulis cerpen dengan konversi teks untuk siswa kelas VII SMP, Jurnal Pendidikan: Teori, Penelitian, dan Pengembangan, 1(7), 1330-1336

Zaini, S.H., Mokhtar, S.Z. \& Nawawi, M. (2010). The effect of graphic organizer on students' learning in school, Malaysian Journal of Educational Technology, 10(1), 17-23 